\title{
Beyond nostalgia in the search for identity: Black liberation theology and the politics of reconciliation
}

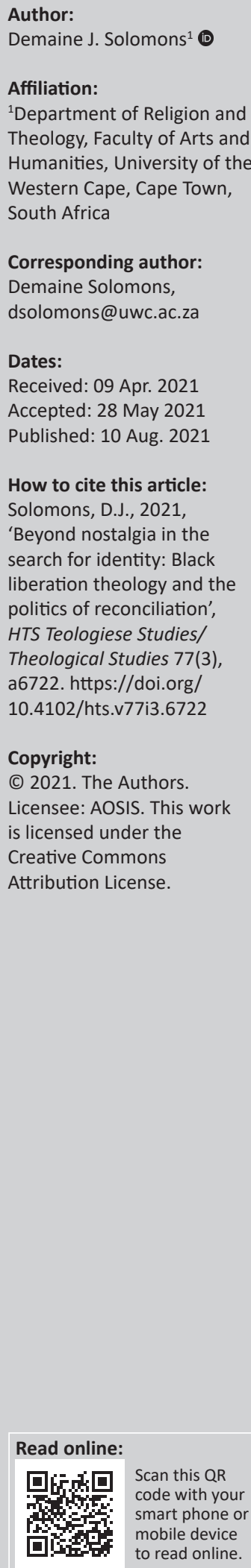

Practitioners of Black liberation theology often reflect on the emergence of this theological expression by means of a nostalgic launch into the past, seeking ways to address some of today's most pressing concerns. In this sense, much of what is known about Black liberation theology, including its identity, is premised on how we engage with nostalgia. However, the problem with the rendering of history through a nostalgic lens is our propensity to populate this reality with half-truths; in the process, we present an idealised version of events, sometimes ignoring the objective facts at our disposal. This is most evident in the tendency to look back at the 'best' of the past whilst comparing it with the 'worst' of the present.

Contribution: The purpose of this contribution is not to focus narrowly on what Black liberation theology (or its practitioners) has done well because this has limited value. Instead, a more productive undertaking necessarily includes what the late Vuyani Vellem refers to when he asks the question: 'What lessons has Black theology not learned?' Often regarded in binary terms, liberation and reconciliation as root metaphors in Black theological thought provide a framework through which practitioners are challenged anew to reflect on some of South Africa's most pressing concerns.

Keywords: black theology; identity; nostalgia; liberation; reconciliation; South Africa; apartheid; democracy.

\section{Setting the scene ${ }^{1}$}

The significance of Black liberation theology is an ever-present reality on the South African theological scene. Practitioners of Black liberation theology often reflect on its emergence by means of a nostalgic launch into the past, seeking ways to address some of today's most pressing concerns. In this context, much of what we know about Black liberation theology, including its identity, is premised on how we engage with nostalgia. Instrumentalised, nostalgia serves an existential function by reinforcing a sense of meaning by drawing on a period that was its events, possibilities and personalities. In this sense, the human propensity to be nostalgic dictates much of how we navigate life. This is what Salmose (2019) alludes to when he says, 'Nostalgia Makes Us All Tick'. This illuminating synopsis provides an essential point of reference, especially in an era where many obsess about the present in relation to the future whilst ignoring the beauty, in some cases the tragedy of historical continuity. On this point, Bauman's Retrotopia (2017) provides a framework for our connection with the present and how this intersects with our understanding of the past. Properly understood nostalgia derives its stimulus from the need to rectify the failings of the present through the resurrection of the forgotten potentials of the past. This is how Bauman defines the retrotopian ideal. Thus, as an existential force, nostalgia provides us with particularity, a perception of reality that gives meaning to our current predicament. Moreover, it provides a framework through which we can better understand the present in the light of our history, both individually and collectively.

The problem with nostalgia as is quite often the case is our propensity to populate reality with half-truths; representing an idealised version of events, and often ignoring the objective facts at our disposal. In South Africa, with so many competing interests, one need not think very hard to come up with examples validating such an assertion. The typical pattern that emerges is the jettisoning of failures (or non-success), favouring that which provides the most utility. Under these circumstances, triumphs are exaggerated and defeat downplayed or, even worse, ignored

1.Some aspects of this contribution are derived from a more extensive 2018 doctoral study in which the discourse on reconciliation is explored (Solomons 2018).

Note: Special Collection: New Landscapes in Identity: Theological, Ethical and Other Perspectives, sub-edited by John Klaasen (University of the Western Cape). 
or rejected. Musto (2019) picks up on this point when he warns that the rose-coloured glasses of nostalgia always lead to an unfair distortion of objective reality. This is most evident in the tendency to look back at the 'best' of the past whilst comparing it with the 'worst' of the present. By way of example, in South Africa, those who formed part of the antiapartheid struggle and the events through which they are depicted are often described in heroic terms. The danger of overstating their contribution individually or collectively is not that obvious, given the significance of the anti-apartheid movement. This is in sharp contrast to the proponents or supporters of apartheid. Generally, they are considered abhorrent, perhaps even evil, given their role in creating the South African predicament. However, unlike those involved in the anti-apartheid struggle, overstating their complicity is easier; some would say acceptable, given the effects of apartheid on contemporary society. In this sense, the reasons for arriving at such a conclusion might be obvious for some. However, on its own, the rendering of history in binary terms, as with this example, does not account for the nuances on both sides of the political and ideological spectrum. At best, what remains is a polarisation of views, where the merits or demerits of the situation on both sides are not dealt with at a granular level.

This binary pattern is also reflected in the various theologies arising out of the apartheid situation. On this front, Maluleke (2000:20) reminded us that until the early 1990s, South Africa was one of the foremost theological contributors globally, producing some of the best and worst representations of Christian theology. The emergence of theologies in support (and defence) of apartheid, better known as apartheid theologies, need not be repeated here (see Vosloo 2015). Nevertheless, those associated with its development were found wanting, condemned to nothing more than the bigotry that their ideas are believed to have symbolised.

In contrast, theologies of liberation occupy a different space altogether; its emergence celebrated and its proponents revered. This is especially the case when reflecting on the history and significance of Black liberation theology in South Africa; here, the urge to be nostalgic given the importance of this theological development is quite palpable. However, upon closer reflection, one quickly realises that most commentaries documenting its emergence have a predominant focus on the best there is to offer, whilst ignoring or simply not doing enough to highlight some of the obvious shortcomings. Not surprisingly, the framing of Black liberation theology in opposition to apartheid (theologies), or racial injustice more broadly, creates a self-validating loop in which it becomes quite tricky for its practitioners to engage self-critically in any meaningful way. Instead, nostalgic imaginaries populate the meaning and substance of Black liberation theology in opposition to a system like apartheid that was evidently unjust, giving credence to suggestions that it is 'locked in yesterday's politics', having 'slept through the revolution which swept through the country' (Tlhagale in Moore 1992).

\section{Black liberation theology: What have we not learned?}

The limitations of nostalgia as a lens to assess Black liberation theology in South Africa are self-evident, at least for those who resist the romanticised rendition of its development keeping in mind that this could probably be said about most, if not all, theological gestations anywhere else in the world. Nevertheless, the purpose of this contribution is not to focus narrowly on what Black liberation theology (or its practitioners) has done well because this has limited value. Instead, a more productive undertaking necessarily includes what Vellem (2017:2) refers to when he asks the question: 'What lessons has Black theology not learned?'. On this front, Boesak's (2019) latest offering, Children of the Waters of Meribah. Black Liberation Theology, the Miriamic Tradition, and the Challenges of 21st Century Empire is an excellent example of someone grappling and providing a systematic framework on ways to address this pertinent question. It is important to note that Boesak does not use the word nostalgia; nevertheless, there is a clear attempt to disrupt whatever illusions the practitioners of Black liberation theology may be suffering from, especially if historical negationism is at the top of mind.

Reflecting on the many challenges facing the country, for Boesak (2019:xiii-xxv), other than the collapse of apartheid in simplistic terms, there are many more challenges that need to be addressed: the plight of women, the overarching theme of this book being one of them. In this sense, Black liberation theology (or its proponents) has been less than forthcoming as far as the ongoing struggle for justice, dignity and women's agency is concerned. According to Boesak (2019):

Women have tried to teach us, but we have not always listened well enough. As a result, more than forty years later, a new generation is asking the question, 'What lessons have Black liberation theology not learned in these years?' (p. xiv)

Boesak's synopsis is compelling, striking a balance between what Black liberation theology offers but being mindful of its many shortcomings and in the process opening the door for a reappraisal: a way for practitioners to reinvent or reimagine what this form of theologising is about. From that vantage point, this goes beyond proposals such as theologies of reconstruction' during South Africa's transition, which declared Black liberation theology passé now that 'freedom' has come and 'apartheid' was over (see Villa-Vicencio 1992). If anything, this is an indication that the struggle for liberation for marginalised groups was far from over and that the concerns over poverty, unjust economic systems, racism and social justice, amongst many other things, remain a serious challenge; this is lamented by Pillay (2020:2) in an aptly titled contribution focussing on the future of this theological discourse in South Africa. With this at the top of mind, concerns over the relevance of Black liberation theology are somewhat of a moot point because its purpose has always transcended political utility; in other words, it has always been about more than a simplistic focus on apartheid. This view is also emphasised by Tshaka and Mafokane (2010), 
focussing on the 'Continued relevance of Black liberation theology for Democratic South Africa today', the title of a provocative research essay.

\section{Black liberation theology: A theology of reconciliation?}

Returning to the earlier question, 'What lessons has Black theology not learned?' followed by more questions regarding the usefulness of Black liberation theology in contemporary society? Here one might be inclined to think that the question emerges not out of concern over the relevance of Black liberation theology, nor is it about theologies deemed more appropriate for the democratic context. Instead, this question alludes to the need for a reorientation of Black theological thought. Whichever way one sees this, the question alludes to something that is already there, but for various reasons, it might not be the most in vogue theological supposition. As noted here, following debates on theologies of 'reconstruction' as an example, it becomes apparent that even theological reflection is not immune to topics considered 'fashionable' in the narrowest sense of the term. In this sense, the relationship between liberation and reconciliation as key precepts in Black theological thought is particularly important for this contribution. Interestingly enough, both terms have fallen out of favour as far as the theological reflection in South Africa is concerned. The following two points are important in this regard.

Firstly, for reasons linked to the dawn of democracy in the country, 'liberation' as a root metaphor in Black theological thought is no longer taken for granted, especially by those who believe the democratisation process renders it obsolete. Vellem (2007:16) reminded us that at the time, some scholars went as far as declaring Black liberation theology to be moribund if not harbouring the danger of reversing racism where the black majority was in political power. Properly understood, the dawn of democracy is an essential variable in emerging theologies (i.e. theologies of reconstruction) seeking to replace, or at the very least subsume liberation with strategies deemed more apt for the post-apartheid context. The aim here is to detach liberation from the black interlocutor on the presumption that blacks are liberated.

Secondly, practitioners of Black liberation theology have had long-held suspicions over the usefulness of 'reconciliation', mainly if that includes diversion or avoiding some of the root causes of conflict in society. In this context, reconciliation is deemed a possibility on the basis of (following) justice. For this reason, practitioners of Black liberation theology often find it necessary to talk about 'true', 'genuine' or authentic reconciliation, thereby implying a rejection of forms of reconciliation considered 'cheap' or 'inauthentic' as observed in the Kairos Document (see ed. Leonard 2010:15-17). Enjoying premier status in accounts of South Africa's democratic transition, in contrast, today, the pursuit of reconciliation is often regarded as an exercise in the absurd (Solomons 2020:411).
Notwithstanding the contested nature of both liberation and reconciliation, James Deotis Roberts, one of the pioneers of the Black theology movement in the United States, provides good reasons why liberation and reconciliation remain essential facets of Black theologising in situations of conflict. In the process, Roberts provides vital clues on developing a framework for Black liberation theology in the contemporary context. Counterintuitive to both the proponents of theologies of reconstruction and many practitioners of Black liberation theology, both liberation and reconciliation are highlighted as key drivers.

In two extensive contributions Black Theology in Dialogue (Roberts 1987) and Liberation and Reconciliation: A Black Theology (2005), Roberts explains the reciprocal link (between liberation and reconciliation) as something that finds its grounding in Christ's salvific will and mission. In so doing, Roberts (1987:18) exposes the inconsistencies of the human condition that sin effects both the oppressed and the oppressor and that in an ironic twist, 'sometimes the oppressed are also oppressors'. Every so often, the oppressed of erstwhile are the oppressors of today. Roberts concludes highlighting that 'God cares for the oppressed, but that God also has salvific concern for the oppressors', whoever that might be. In this context, reconciliation is essential and cannot stand alone and apart from liberation. This then goes against the urge to absolutise one root metaphor. At the very least, this also raises questions over subsuming some root metaphors that, which we believe, provide the most utility at any given moment.

Considering this, it is not surprising that liberation and reconciliation came under scrutiny in Christian theological reflection in South Africa after 1994. One may suggest that such theological concerns have to do with the search for appropriate theological models and root metaphors. As an agenda for Black theology, liberation and reconciliation offer one such possibility, but 'ecclesial unity', 'justice', 'nationbuilding', 'human dignity' (ubuntu), 'reconstruction' and 'development' offer alternatives. At the very least, the question with reference to the connection between liberation and reconciliation simply has to be addressed. How, for example, is liberation related to reconciliation theologically and methodologically? Should reconciliation follow upon liberation or vice versa? How are liberation and reconciliation between different social groups related to the liberation and reconciliation offered in Christ? What connotations are attached to these critical concepts in Black theological reflection? As observed earlier, this is not about the invention of something new, but rather a reappraisal of something already in existence. The important thing now is to highlight why the liberation-reconciliation link is crucial in coming to terms with the multifaceted identity (if one can call it that) of Black theological reflection.

\section{Beyond binary distinctions}

Conceptually then, how does one strike a balance between what liberation offers whilst also staying true to the reconciliatory ideals contained in Black liberation theology? 
Necessarily, this requires something beyond the binary distinctions presented here. The arguments for and against liberation and reconciliation are well documented. However, this alone does not bring us any closer to addressing the more substantive matter concerning the role of Black liberation theology today. As observed earlier, Boesak's (2019) Children of the Waters of Meribah provides important clues that help us provide answers to Vellem's question.

In the same way, Roberts in Liberation and Reconciliation (2005) provides good reasons why liberation and reconciliation presuppose one another, if God's liberating and reconciliation act in Jesus Christ is to be considered. In other words, they are not antithetical, nor are they mutually exclusive, and should not be treated as such. The temporal sequencing of root metaphors, either through an overemphasis on some or another metaphor, creates a binary distinction that is, for the most part, misplaced. It further creates an environment where some are forced to align themselves with political and ideological subgroupings, creating a misapplied sense of purpose.

If Volf's (2000:867-868) comments concerning the broader pursuit of justice are considered, one could justifiably make a case why liberation should form part of a broader pursuit of reconciliation. Here, the struggle against all forms of injustice is aligned to the creation of a reconciled society. Therefore, in pursuing a just cause, liberation does not subsume reconciliation in the same way that liberation cannot be relegated because of reconciliation. It is, thus, on both sides of the political or ideological spectrum, misdirected to focus on the one and ignore that to which it is inextricably tied; if anything, this perceived tension drives one to be more mindful of the intimate nature of these theological suppositions. In the light of the Christian understanding of God and humanity, liberation and reconciliation in no specific order should move naturally from one to the other. Depending on the situation, it might be understandable why there might be an overarching focus on a particular root metaphor at certain times, but this should always be performed with the others at the top of mind.

However, Frostin's (1988:169-176) analysis of Black liberation theology in South Africa indicates that this might be easier said than done given the contested nature of such ideas. This is especially the case with theological discourses on reconciliation where opposing factions often have specific, often conflicting thoughts on how a ministry of reconciliation needs to be pursued (Solomons 2019:96-100). Historically this is the case for those who supported and those who opposed the apartheid system. To illustrate, the controversial Dutch Reformed Church document, Ras, Volk en Nasie en Volkeverhoudinge in die Lig van die Skrif (Nededuitse Gereformeerde Kerk 1974), the theological justification of apartheid, is a good example of the counterintuitive use of the reconciliation concept. According to Loubser (1987:24), those who supported the document believed that the unity of God's creation marks a divine calling to enact ethnic differentiation, which would allow all races to fulfil their own destiny, individually along racial lines. Controversially, this provided the basis for a possible faith relationship between apartheid and a Christ-centred understanding of reconciliation.

In contrast, the practitioners of Black liberation theology often had to deal with the need to work towards the visible unity of people in church and society. Amongst other things, this included reconciliation in terms of mending black and white relations: an approach that caused a fair amount of controversy, especially amongst the proponents of the Black Consciousness Movement who argued that reconciliation (or social integration) before achieving liberation fundamentally undermined the liberation project (De Gruchy 2002:34). In other words, for them, reconciliation should only be pursued once apartheid structures had been abolished. In this sense, the need for political, economic and cultural liberation was emphasised. Here the assumption was that social justice can only follow upon liberation and that reconciliation is only possible on the basis of (following) justice. This approach is evident, especially in the Kairos Document. Rhetorically, this related not to reconciliation as a necessary strategy but rather the means of how this ideal is to be achieved.

Underlying much of the scepticism is the idea that reconciliation can be brought about instantaneously, provided the conflicting parties have a change in mental attitude. On the contrary, some believed that reconciliation could only be achieved once concerned parties let go of their privileged position. Frostin (1988:170) describes this impasse, if one can call it that, synchronic and diachronic approaches to reconciliation. The synchronic approach suggests that mutuality is instantly achievable through a mere change in mental attitude. On the contrary, the diachronic approach associated with proponents of Black liberation theology charged that reconciliation could only be achieved through a process where all parties are liberated from their different types of alienation. Anything other than this results in a situation where the distinction between 'authentic' as opposed to 'cheap' reconciliation often needs to be made. This explains why the Kairos Document and those who supported it denounced a reconciliation that presupposes liberation. In defence of this position, Schreiter (1992:25) insists that in situations such as the one faced in South Africa, one should resist the temptation to forward reconciliation as an alternative for liberation. Moreover, that liberation remains a necessary precondition for reconciliation. In this context, he argues that 'calls for reconciliation can provide a goal for liberation, but they can never replace it'.

\section{Black liberation theology and the politics of reconciliation}

Given this discussion, within reason, one could make a case why, in the democratic context, liberation and reconciliation, as root metaphors, deserve a seat at the proverbial table of Black liberation theology. However, one would have to contend with concerns over the potential of this theological expression to effectively address some of the challenges 
concerning the strained race relations in the country. Again, it has been implied that the abolition of apartheid and the democratisation of the country render Black liberation theology obsolete. However, it should be noted that political rather than theological considerations are often cited as a key driver behind such concerns. Nevertheless, from an ontological perspective one should be mindful that the Christian faith, and Black liberation theology in particular, as alluded to by Tshaka and Mafokane (2010), transcends a narrow political understanding of reality. Liberation, in this sense, means much more than political liberation. On this point, Nürnberger (2002:164-203) intimates that the Christian gospel promises a sense of wholeness that is all-encompassing, something that includes but is not limited to political considerations.

If Nürnberger's advice is to be heeded, liberation becomes a crucial ingredient for reconciliation between different interest groups to take place. In this context, those concerned will find it difficult to affirm their own humanity if they evade the quest for the liberation of others. What does this mean for South Africa? According to Tutu (1982:43), commitment to black liberation is inextricably tied to white liberation. Those concerned cannot be free unless the same courtesy is extended to the other. The dawn of democracy, therefore, does not alter this reality, especially in cases where that which was aspired to have not yet been realised. If one is to presuppose a normative theory of humanity, where their solidarity is affirmed, liberation is crucial for both blacks and whites to enjoy a meaningful life regardless of the social markers that separate them (Boesak 1979:173). Indirectly this also addresses the perceived exclusive nature of Black liberation theology, some believing it conforms to the notion of theological apartheid of sorts where whites have no part. On this matter, Boesak (1977:16) warns that generally blacks have a good understanding of the estrangement caused by the absolutisation of ideas. Thus, in his view, it would be inaccurate to project Black liberation theology in exclusivist terms because the available evidence points to the contrary.

Nevertheless, there is no denying that the black experience of oppression is crucial in coming to terms with the identity of Black liberation theology, but that this is not predicated on skin pigmentation alone, rather in affirming humanity in all its guises. Moreover, it is foregrounded in God's preferential option for poor and oppressed people, whoever that might be. In this context, liberation is consistent with the gospel and the content and framework of Christ's atoning work. However, in stating this, one needs to be reminded of the importance of reconciliation in giving flesh to Christ's atoning work. If anything, the question whether reconciliation has a role to play in addressing some of the most difficult challenges facing South Africa at present would have to be addressed. The assumption that it lacks the credibility to do so may very well be contingent on a political instead of a theological understanding of its potential.

According to Boesak and DeYoung (2012), a theological understanding in contrast to a political understanding of reconciliation is radical; this is expressed in their book, Radical Reconciliation: Beyond Political Pietism and Christian Quietism. As the political reconciliation has stalled, now would be an opportune time to retroject the discourse to its theological roots. In giving substance to this interpretation, Boesak and DeYoung (2012:154-155) charge that 'Reconciliation without social justice, equity, and dignity is not reconciliation at all'. Thus, for them, reconciliation is more than mere political expediency especially if this is aimed at accommodating some people at the expense of others. In contrast:

[R]adical reconciliation questions the assumption that justice can be served, social contracts honoured, and solidarity enacted through politics and policies grounded in a neoliberal capitalism whose very survival depends on the exclusion of the powerless, the exploitation of the poor, and the nurturing of inequality the scale of which is devastatingly clear in South Africa. (p. 154)

In discussing the role of forgiveness in the reconciliation process, they maintain that this demands more than just forgetting: 'Reconciliation is holding the memory holy before God as a means of responding to God's demands for justice for the vulnerable and the powerless, the neglected, and the excluded'. In this context, forgiving does not equate to forgetting and moving on but remembering to honour the victims, so the violation is not repeated; this transcends mere sentimentality and finds its roots in the need for liberation. It is for this reason that reconciliation can only take place between equals. This calls for the addressing of personal as well as systemic injustices. The essential point is that the personal and the systemic are inextricably tied to the extent where 'the deeply personal does not cancel out the thoroughly systemic'.

Simply put, the restoration of justice, equity and dignity is central to personal and societal liberation and reconciliation. This goes against the idealism articulated in a political understanding of reconciliation, where it is incumbent upon those in power to set the agenda for reconciliation. In their view, 'Reconciliation emerges from the margins and not from the centers of political or religious power'. In this context, the voices from the margins invigorate the discourse, calling those in authority to join the process meant to 'rehumanise' not just the victims but also the perpetrators of injustice. They further insist that there may be a place for political reconciliation but that on its own will not suffice because a theology of reconciliation demands more.

\section{Inconclusive thoughts}

The quest for liberation and reconciliation provides a framework through which one can address some of the many challenges facing South Africa. Undeniably from this vantage point, the work of Black liberation theology is indeed incomplete. Simultaneously, suspicions relating to reconciliation as an effective strategy (or guiding vision) do not relieve the practitioners of Black liberation theology from working towards the realisation of this ideal, irrespective of how difficult it might be. This calls for something beyond 
nostalgia or a mere focus on what Black liberation theology has done well; instead, this guides practitioners towards a more effective strategy as far as the identity and work of Black liberation theology is concerned. This task is undoubtedly not an easy one, and one should be highly suspicious of anyone presenting it as such. More importantly, those declaring Black liberation theology passé must appreciate that there can be no meaningful attempts to working towards reconciliation without liberation. As it is often projected, the dawn of democracy does not undo the need for liberation. The need for liberation theology is great, and many of the challenges remain a constant reality. If Roberts' (2005:20) contribution is once again considered, 'We must be liberated - Christ is the liberator. Nevertheless, the liberating Christ is also the reconciling Christ. The one who liberates reconciles, and the one who reconciles liberates'.

\section{Acknowledgements Competing interests}

The author declares that he has no financial or personal relationships that may have inappropriately influenced him in writing this article.

\section{Author's contributions}

D.J.S. is the sole author of this article.

\section{Ethical considerations}

This article followed all ethical standards for research without direct contact with human or animal subjects.

\section{Funding information}

This research received no specific grant from any funding agency in the public, commercial or not-for-profit sectors.

\section{Data availability}

Data sharing is not applicable to this article as no new data were created or analysed in this study.

\section{Disclaimer}

The views and opinions expressed in this article are those of the author and do not necessarily reflect the official policy or position of any affiliated agency of the author.

\section{Referenes}

Bauman, Z., 2017, Retrotopia, Polity Press, Cambridge.
Boesak, A.A., 1977, Farewell to innocence: A socio-ethical study on black theology and black power, Raven, Johannesburg.

Boesak, A.A., 1979, 'Liberation theology in South Africa', in K. Appiah-Kubi \& S. Torres (eds.), African theology en route, pp. 169-175, Orbis Books, Maryknoll, NY.

Boesak, A.A., 2019, Children of the waters of Meribah: Black liberation theology, the Miriamic tradition, and the challenges of 21st century empire, Sun Media, Stellenbosch.

Boesak, A.A. \& DeYoung, C.P., 2012, Radical reconciliation: Beyond political pietism and Christian quietism, Orbis Books, Maryknoll, NY.

De Gruchy, J.W., 2002, Reconciliation: Restoring justice, SCM Press, London.

Frostin, P., 1988, Liberation theology in Tanzania and South Africa: A first world interpretation, Lund University Press, Lund.

Leonard, G.S.D. (ed.), 2010, The moment of truth: The Kairos Documents, Ujamaa Centre for Biblical and Theological Community Development and Research, University of KwaZulu-Natal, Pietermaritzburg.

Loubser, J.A., 1987, The apartheid bible: A critical review of racial theology in South Africa, Maskew Miller Longman, Cape Town.

Maluleke, T.S., 2000, 'The rediscovery of the agency of Africans: An emerging paradigm of post-cold war and post-apartheid black and African theology', Journal of Theology of Southern Africa 108, 19-37.

Moore, B., 1992, Black theology revisited, viewed 17 February 2021, from https:// www.benkhumalo-seegelken.de/wp-content/uploads/Black-Theology.pdf.

Musto, M., 2019, 'The problem with nostalgia', Longreads, viewed 21 February 2021, from https://longreads.com/2019/03/05/the-problem-with-nostalgia/.

Nededuitse Gereformeerde Kerk, 1974, Ras, volk en nasie en volkereverhoudinge in die lig van die Skrif: Beleidstuk goedgekeur deur die Algemene sinode van die Nederduitse Gereformeerde Kerk, Oktober 1974, NG Kerk Uitgewers, Kaapstad.

Nürnberger, K., 2002, Theology and biblical witness: An evolutionary approach, LIT Verlag, Hamburg.

Pillay, J., 2020, 'Wither black theology of liberation? Perspectives from the late Professor Vuyani Vellem', HTS Teologiese Studies/Theological Studies 76(3), a6232. https://doi.org/10.4102/hts.v76i3.6232

Roberts, J.D., 1987, Black theology in dialogue, Westminster John Knox Press, Louisville, KT.

Roberts, J.D., 2005, Liberation and reconciliation: A black theology, Westminster John Knox Press, Louisville, KT.

Salmose, N., 2019, 'Nostalgia makes us all tick: A special issue on contemporary nostalgia', Humanities 8(3), 144. https://doi.org/10.3390/h8030144

Schreiter, R., 1992, Reconciliation: Mission and ministry in a changing social order, Orbis Books, Maryknoll, NY.

Solomons, D.J., 2018, 'Reconciliation as a controversial symbol: An analysis of a theological discourse between 1968-2010', Unpublished PhD thesis, University of the Western Cape.

Solomons, D.J., 2019, 'Gustaf Aulén: An unlikely conversation partner and his connection to reconciliation in South Africa', Svensk Teologisk Kvartalsskrift 95(2) 93-108.

Solomons, D.J., 2020, 'The absurdity of reconciliation: What we (should) learn from Rustenburg and the implications for South Africa', Stellenbosch Theological Journal 6(2), 393-412. https://doi.org/10.17570/stj.2020.v6n4.a18

Tshaka, R.S. \& Makofane, M.K., 2010, 'The continued relevance of black theology for democratic South Africa today', Scriptura: Journal for Contextual Hermeneutics in Southern Africa 105(1), 532-546. https://doi.org/10.7833/105-0-155

Tutu, D.M., 1982, Crying in the wilderness: The struggle for justice in South Africa, Eerdmans, Grand Rapids, MI.

Vellem, V.S., 2007, 'The symbol of liberation in South African public life: A black theological perspective', Unpublished PhD thesis, University of Pretoria.

Vellem, V.S., 2017, 'Hermeneutical embers from the "zone of non-being"', Unpublished paper, presented at the council on world mission DARE conference, Bangkok, Thailand.

Villa-Vicencio, C., 1992, A theology of reconstruction: Nation building and human rights, Cambridge University Press, Cambridge.

Volf, M., 2000, 'Forgiveness, reconciliation, and justice: A theological contribution to a more peaceful social environment', Journal of International Studies 29(3), 861-877. https://doi.org/10.1177/03058298000290030601

Vosloo, R., 2015, 'The bible and the justification of apartheid in reformed circles in the 1940 s in South Africa: Some historical, hermeneutical and theological remarks', Stellenbosch Theological Journal 1(2), 195-215. https://doi.org/10.17570/ stj.2015.v1n2.a09 